\title{
Why am I dreaming in html subtitles?
}

\author{
Words of wisdom for new Webmasters
}

\author{
by Lynn Rebbeor Shay and Sherman Hayes
}

$\mathrm{A}$ Imost every library is providing online service, Web accessed data, and a presence on the almighty Web. Key to this Web innovation is the "great and powerful Webmaster" in each library. Well, there are a lot of Webmasters out there. We have found very little guidance and "tricks of the trade" related to this important new position. Thus our noble effort to document a Webmaster's Words of Wisdom.

- Webmaster selection/draft. Be care, ful when they ask for volunteersyou may become a Webmaster! The path to this prestigious work is unclear as the new "position" evolves. We have seen for the first time, some ads for actual "Webmaster" positions. How: ever, most libraries combine it with other duties. One lesson is to make sure that you get more money, definitive authority to do the job, and a title is good because the outside world at least knows you are in this business. The field is so new, there are no clear studies on how one can get out of being the library Webmaster.

- The title. It is not good practice for the Webmaster to take the word "master" in their title too seriously. You need task forces, com- mittees to help, coordinators who assist if you are in a large institution, and even management support of the Web design and maintenance process.

Who is on these various committees is critical to your success and health as a Webmaster. The page incorporates the diversity of information and knowledge in your library and represents the diversity and knowledge of all employees in the library.

People will surprise you with actual good ideas! As Webmaster, be prepared to manage an ever changing set of committees and task forces. You may be in charge, anyway that is what your title indicates, but you need to accommodate the needs of almost every staff member when it comes to the functions of the page.

- Webmaster as artist. In design, everyone is a self-proclaimed artist. You can't win with colors. You can't get unanimous consensus on typeface or bells and whistles. In the end, the organization and layout is really the key component, so we suggest you compromise on art and then change it later when they are not looking. (Just kidding!)

- KISS. "Keep It Simple Stupid," although a cliche statement, has some real value in

\section{About the authors}

Lynn Rebbeor Shay is assistant manager of reference and information services and library Webmaster at the University of North Carolina at Wilmington, e-mail: shayl@uncwil.edu; Sherman Hayes is university librarian at the University of North Carolina at Wilmington, e-mail: hayess@uncwil.edu 
design of Web pages. There is a great temptation to show off your facility with neat animation, multiple colors, banners, and, of course, the infamous "blinking dots. . .." While you may be thrilled with your fancy look, the reality holds that most people who look at your page are waiting precious seconds (or to them minutes) for it to load.

- Design, design, design. While most people start with worrying about the look of the page, the true creative design work is in structuring the page to help people effectively get where you want them to go and even more so, to get where they need to go! In the "Webmaster trade," you need to worry about how many clicks it takes to make a satisfied customer.

There are really some important issues related to how people approach information. (You thought this article was going to be all fluff!)

1. Remembering the goals of the page, how many pointers to other subpages can you and should you link from the first page?

2. Should you use lists with individual links or pull down menus?

3 . Or should you use both?

4. As a wider audience gets used to search engines, should you include that feature?

5. How prominent should your internal "stuff" be versus the outside content of the Web? Do cataloging rules and internal procedures (important as they are) need to be your lead entries?

6. Color choices need to be tied to goals of instructing the patron about your page and what it can accomplish.

- "A little dab will do you." Don't over design. In today's online world, the customers are using a tremendous variety of connecting machines, service providers, and they even vary in their own skill levels. We have proxy servers that allow our students, faculty, and staff to access our page and its contents anytime, anywhere from the Web. The design of the page for this type of access is very different from a library that has machines in clear helping distance of the reference desk.

- Thoughtful sharing. You don't need to recreate the wheel. Now there was an uncommon cliché! Look at other institutions for good ideas to build on and watch for practices to avoid.

- Content, content, content. The real challenge of Web page design is deciding on the content that needs to be included and deciding the best ways to guide your patrons to that content. Surprise! That is what librarians have been doing forever. Skills that are most critical to this task are the skills of librarianship we all, hopefully, share. People mistakenly want to start with the "sizzle," but you really need to start with the "meal." A good Webmaster is first and foremost a good librarian who reminds people that this exercise is part of our core service delivery system.

- Crisis manager. Seldom do you have the luxury of deliberate planning and thoughtful re-design. Something happens-there needs to be a change on the page and because it is computing, it must be done now! A Webmaster needs to anticipate these mini-emergencies and even drag his or her feet on occasion to determine if the world will collapse if this change is not made immediately.

- Bilingual. You will need to learn a new language called html (or one of its ever-expanding variations). The software has gotten better and you may not need to feel like a programmer, but you still need a feel for this language to be successful. Lynn is taking Spanish now, and is surprised that she can handle two new languages at once. People can tell you what they think they want (what the university librarian wants is not always clear, but one does have to listen and try to help him or her), but it is still up to you, as Webmaster, to translate that into this coding language to make the page happen.

- Interdependence. No matter how independent you may think your library is, when it comes to Web pages, there is almost always a university or college Webmaster looking over your shoulder. The parent institution imposes standards, common looks, and connections to the university or college page that you must follow. This is really a very logical and sound practice, even if the university Webmaster doesn't have a clue as to what the library does. Often, the library Webmaster is automatically part of a cam- 
pus-wide design committee. Our experience is that we have had to assert ourselves, our Web page, and our goals to make sure that the overriding promotional aspects of the university page doesn't do disservice to our efforts.

- Consortia. If you belong to a consortium, this, as in all things related to cooperative ventures, will add new layers of complexity to the Web page. In our three- library-cooperative life, we decided to have three separate Web pages. Every library doesn't have the same needs, equipment, and such. Fortunately, you can have individual pages and still do very creative connections between partner schools.

- Prestige? You, as Webmaster, may get invited to important meetings when big shots want to stress the high tech nature of the

\section{Research topics}

As a final service to fellow library faculty seeking publishing topics, we offer our suggestions for needed research in this new area of library Webmasters.

- Who are today's library Webmasters? Demographics, background, training, strange work habits, computer health, and other profiles.

- Are the library schools providing the skills necessary for the next generation of Webmasters?

- Is there a dress code for Webmasters that has proven effective in getting promotions?

-Where does the position "Webmaster" fit into today's and future library organizations?

- Are libraries losing or will they lose these talented "not geeks really" people to the private business world?

- How does the library Webmaster interface with the greater university or college computing community?

- How many Webmasters does it take to change a light bulb?

- What careers paths do Webmasters choose after they quit being Webmasters? Or is retirement the only option? library. Be careful not to assume this high tech mantel too seriously. Everyone on the staff contributes to technology, not just the Webmaster.

- You've got mail! Web pages usually offer the user an option to e-mail the Webmaster. Webmasters are expected to read the questions and comments. And do people ever comment. You do get mail. Some of it is helpful, some will be weird. Many companies have decided that the Webmaster is the person to receive information about their new products. Lucky Webmaster.

- Web talk. It is not required that Webmasters be geeks. They do have to fight against Web talk. Not everyone on the staff is html fluent, nor do they want to be. That's why they support you in the role as Webmaster. However, when you taik with other people on campus who manage pages or other librarians who are Webmasters, you should be able to quickly fall into the patter of html speak.

- Next generation Webmasters. Many of the current Webmasters were plucked from their staffs due to interest, or they missed a committee meeting when the appointment was made. As a Webmaster, do not begin to think that you are so special that no one else can do this job. We have noticed that library school graduates seem to be more and more Web savvy. In fact, keeping up with new graduates may be the next generational challenge for Webmasters. Hey, someone needs to say that the library schools are doing a good job in this area of the Web world.

- Never done! The Web page has a continuing life. You have the privilege of working on a permanently unfinished product. It is never done and can always be improved,

added to, redesigned, upgraded, or recolorized. Your library will add new electronic sources, new procedures, change its hours, add staff, etc. etc. etc. Be careful to avoid change for change's sake. Would you redesign a printed document daily? Since everyone thinks they are a designer and a wannabe Webmaster, the suggestions never 
transportation in Europe, and lodging and board for a period not to exceed 14 consecutive days.

Larson plans to use the grant for travel to Rome and Paris to gather research at the Vatican Library and Parisian archives for his study, "Documenting the Dissemination of the Gregorian Calendar Reform in France During the Wars of Religion."

John Cullars, chair of the Western European Specialists Section (WESS), said, "Jeffry Larson's is a fascinating bibliographical study that will be of interest to historians of the Reformation and Counter-
Reformation and of Renaissance France, including historians of science and of social attitudes, the librarians who assist them, and those who ask themselves, "Where did the missing ten days of our calendar go?'"

He has served as the editor of the Romance Language section of Reference Reviews Europe, and is the former editor of the WESS Newsletter.

The award will be presented at the WESS General Membership Meeting on Monday, July 10 , at 11:30 a.m. during the ALA Annual Conference in Chicago.

\section{("Job Shadou' Day . . " continued from page 296)}

activities to a format that best works for them.

- Wayne State University (WSU)-Detroit. WSU's undergraduate library hosted 60 middle- and high-school students. This initiative is especially important for the Detroit area since current hiring data revels that minorities only represent $9 \%$ of academic librarians and less than $12 \%$ of all students enrolled in $\mathrm{Li}-$ brary Science programs.

The students spent the better part of the day at the library. The librarians at the Undergraduate Library thought this was such a successful event that they are considering presenting their summary in an extended format, such as a poster session at an ALA or ACRL conference.

Job Shadow Day participant Kia Drake, a ninth grader at Detroit's Martin Luther King high school said, "When MLKing's 9th grade CPLA (College Prep Liberal Arts) stuclents attended the Wayne State Undergraduate Library trip, at first I thought it was going to be boring, but when we got there it was interesting to see all of the college students at work. I learned

(Why am I dreaming

page 301)

end. (Since you change the page, it is easy for others to suggest work for you.)

Finding a balance between being overwhelmed in Webmaster land, and actually thoughtfully improving the page is a difficult part of the job. Check out our "permanently unfinished product" at http://library.uncwil. edu. that the library is not just books and being quiet, but it is about learning new things. I learned how the library runs all of the time and how much fun it would be to work there. I had fun playing on the Internet looking for different references. This trip was fun and I would love to go again."

\section{It's not too early to start planning}

As the ALA Divisions Job Shadow Day continues to develop, we hope that the groundwork shared by this year's participants will be useful for an increasing group of library participants.

ACRL encourages all libraries to start planning now for next year's Job Shadow Day on February 2. The Job Shadow Day Planning Kit developed for this year's participants will be updated for 2001 and will remain on our Web site at www.ala.org/acrl/ jobshadow.pdf.

Questions should be directed to Margot Sutton, ACRL Job Shadow Day coordinator, (800) 545-2433, ext. 2522; e-mail: msutton@ ala.org.

Although we have chosen to take a slightly humorous tack on this subject (we know, you are uncertain of the humor), it is really a growing area of service and design in every academic library.

Please share with the greater library community your stories of Web successes and failures so that all can benefit from your words of wisdom. 